\title{
ИСКУСУВАҢЕТО НА СВЕТОТО: ЕМОЦИОНАЛНИ АСПЕКТИ НА РЕЛИГИОЗНОТО ВЕРУВАЊЕ
}

\author{
Марија Тодоровска ${ }^{1}$

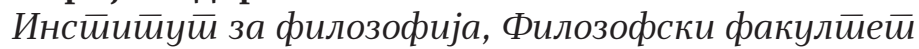

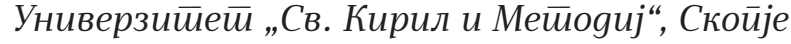

\section{Кратка содржина}

Во овој текст е направен обид накратко да се истражи односот меѓу разбирањето на искуството на светото во изучувањето на основата на религијата, и сложената емоционалност на религиозниот живот, како и да се укаже на дел од емоциите што искусувањето на светата (или нуминозната) реалност ги предизвикува, низ три главни точки: искуството на светото од страна на религиозниот човек (homo religiosus) во теориите на P. Ото (R. Otto) и M. Елијаде (M. Eliade); врската меѓу Јунговиот концепт за архетиповите и парадигматската важност на митовите како свети сказни; и чувството на непријатно непознатото како профан (квази) еквивалент на чувството на нуминозното. Во овие рамки, концептот на светиот простор, како суштинска онтолошка категорија во истражувањето на светото, е кратко објаснет како формативен за функционирањето на религиозниот култ и религиозното верување, како во архаичните заедници, така и одржувајќи се во современ контекст.

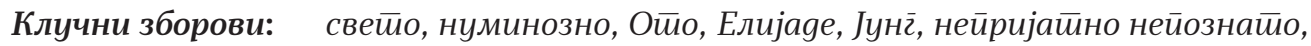
архейий.

marija.todorovska@fzf.ukim.edu.mk 
Во овој текст ќе биде направен обид да се покаже заемниот однос меѓу разбирањето на светото во изучувањето на религијата и емоционалните аспекти на религиозниот живот, односно доживувањето на емоциите што се јавуваат при искусувањето на светото (или нуминозното). Ова ќе биде разгледано низ основните концепти за светото искуство (односно искуството на светото) низ две клучни теории за светото (на Р. Ото/R.Otto и на M. Елијаде/M. Eliade), како и низ нивното (претпоставено) влијание врз К. Г. Јунг (K. G. Jung). Со тоа, ќе бидат разгледани и светите простор и време како суштински онтолошки категории во истражувањето на светото, поради нивната круцијална важност во религиозниот живот на верникот, како во примордијален (или архаичен) контекст, така и во современиот контекст на силно профанизирано (или десакрализирано) живеење.

Овој текст е одговор на темата на симпозиумот „Психологија за сите“, но не е текст од областа на психологијата, туку кратко интердисциплинарно промислување на емоционалноста на homo religiosus (религиозниот човек). Религиозните и емоционалните аспекти на искусувањето на светото се анализирани низ концептите за нуминозното на Ото, низ разбирањето на Елијаде на парадигматичноста и перформативноста на митот како основа на религијата, и преку употребата на архетиповите кај Јунг. На крајот ќе бидат споменати идеите за светото, односно нуминозното, како нешто сосема друго, и она што може да се смета за негов профан еквивалент, чувството на непријатно непознатото.

\section{Позиционирањето на светото во основата на религиозното искуство}

Според една од главните теории за потеклото и за природата на религијата, светото лежи во основата на религиозното искуство, со што е клучна категорија во животот на homo religiosus, независно дали се работи за верник од архаичните заедници и примордијалните облици на религиозниот живот, или современите искуства на верата во монотеистичките религиски системи. Во верувањата во кои светото е во центарот на религиозниот живот, светот се дели на две јасни и разделни подрачја. Светото подрачје е вредно, супериорно, заслужно за уреденоста и преуспевањето на средината и на заедницата, моќно, недостижно, извонредно, а профаното подрачје е секојдневно, вообичаено, познато, помалку вредно. Меѓу овие две подрачја, или два света, постои еден вид на радикална хетерогеност, или исклучителна дисјункција. Ова е, меѓутоа, иницијална примарна поделба, затоа што додека е точно дека меѓу нив постои онтолошка инкомпатибилност или јаз (ако нешто е свето не може да биде профано, и обратно), меѓу нив не постои бездна, тие се меѓусебно завис- 
ни, поврзани, и во постојан однос на двојна спрега - светото го произведува и одржува профаното, кое го штити и одржува светото. Кога не би постоела никаква релација меѓу нив, освен таа на меѓусебно исклучување, не би постоел религиозниот култ.

Еден од најпознатите ставови во врска со логичкиот однос на светото и профаното е тој на Диркем - во историјата на човековата мисла не постои дихотомија како таа на светото и профаното, нема друг пример на две толку длабински диференцирани и толку радикално спротивставени категории, Durkheim (1968, 53). Идејата за светото на Ото е идеја за реалност што ја трансцендира нашата моќ за рационално познание. Светото не припаѓа на обичното подрачје на профаното живеење, тоа е супериорно и нешто кон кое верникот се стреми. Тое е недефинирливо, непоимливо, но може да се опише преку аналогии и метафори. Чувството што го предизвикува е чувство на треперење пред застрашувачката, ужаснувачка мистериозност, пред моќта која плаши со нејзината преобилност и туѓост. За Ото, светото е нешто сосема друго. Нуминозното во себе има елемент, или момент, што ѝ се измолкнува на рационалноста, земена во повисока смисла: тоа е моментот на arreton - ineffabile - неизречивото, тоа што е сосема недостапно на какво било поимовно разбирање, Otto $(1920,5)$.

Компоненти на нуминозното се страшната и фасцинантната мистерија, енергијата и величественоста. Мистеријата, земена во чисто природна форма, прво значи само тајна или мистерија во смисла на она што ни е туѓо, непознато, неразбрано и необјаснето, со што mysterium е аналоген поим земен од природната сфера, што го илустрира овде потребното значење, но нема способност потполно да го долови. Затоа, Ото ја воведува конструкцијата йоййолно различно или найолно gруг̄o - ganz andere (thateron, anyad, alienum), за мистериозното во религиска смисла. Наполно другото е сосема над сферата на вообичаеното, интелигибилното, поимливото, познатото, тоа излегува од овие граници и го исполнува духот кој го препознава со растреперено чудење, вчудовиденост и трогнатост. Во Послание gо Римјанийе, Барт (Barth) се осврнува на Свейойо на Ото со големо задоволство. Така, тој резимира дека „субјектот има психолошка ориентација, но јасно излегува од нејзината граница во она над или отаде, со моментите на нуминозното кое не треба да биде рационално конципирано, затоа што е нешто сосема друго, божественото“ (Barth, според Almond, 1984, 4). Нуминозното, односно сосема другото, е над разумот, но и над каков било човечки труд, тоа е извор на вредност, односно на повисок онтолошки статус, безбедно позиционирано надвор од кризата на овдешниот свет.

За Елијаде, секоја хиерофанија е кратофанија - во секоја екстериоризација на светото има сила, моќ, со необјаснива природа на извонредност. Кога вер- 
никот го искусува светото, се транспонира во подрачје на моќ, на онтолошка супериорност, на чисто време, специфичен простор, подрачје на значајно постоење. Пројавата на светото го укинува профаното: во навлегувањето во свет простор, или постоењето во светото време, раскажувањето на светиот мит и изведувањето на светиот ритуал подразбираат промена на идентитетот на верникот: од профан човек во вообичаената сфера на секојдневието, тој станува дел од извонредната потопеност во моќта на светото, човекот и самиот е (делумно) свет. Онтолошката разлика меѓу светото и профаното е по вид, не по степен - се работи за различни реалности од кои едната е помоќна, позначајна и во секој важен аспект супериорна над другата. Сепак, овие два вида се нераскинливо поврзани во нивната меѓусебна зависност и потреба од одржување.

\section{Митовите како парадигми - Јунг и Елијаде}

Според Елијаде и други теоретичари на религијата кои инсистираат на примарноста и важноста на митот, митовите се свети сказни во кои се раскажува за космогонијата, за уредувањето на елементите на светот во иницијалното пројавување на светото, за настанувањето и за дејствата на светите предци. Раскажувањето на митовите во религиозниот култ предизвикува реактуализација на тоа изворно, онтолошки супериорно време. Митовите имаат и перформативна функција: дејствата на светите предци наложуваат начини и схеми на однесување на членовите на заедниците, тие воведуваат во постоење одредени аспекти на реалноста. Митовите пропишуваат како треба да се живее: соодветните, правилни, прифатливи и препорачливи начини за изведувањето на сите обврски го имаат своето потекло во светите митови (правилата и ритуалите на култот, работните обврски, лекувањето и одржувањето на јавното здравје); во митовите се наведени и пропишани и сложеностите на интерперсоналните односи. Митовите како свети сказни служат како парадигми за однесувањето во светото време, и индиректно, за однесувањето во профаното време.

Врз основа на концепцијата за колективните претстави од француската социолошка школа и симболичкото толкување на митот, Јунг развива хипотези во врска со длабочинскиот, колективно несвесен дел на психата. Од четирите основни функции, мислењето, чувствувањето, интуицијата и осетот, едните се во областа на свеста, и со тоа се доминантни, а другите му припаѓаат на несвесното, врз што Јунг го става акцентот. Во фантазијата и соништата на човекот му се појавуваат ликови или мотиви од митот. Оваа длабока колек- 
тивна внатрешност на несвесното е резервоар на архетипови. ${ }^{2}$ Јунг ги зема

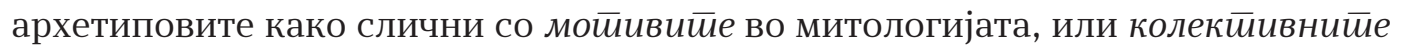
$\bar{u} p e \bar{u} c \bar{u} а в и$ од француската социологија, како и (со резерва, затоа што се работи за силна симплификација) со априорните идеи кај Кант. За Јунг митовите се првобитните „откровенија“ на претсвесната душа, ненамерни изрази на несвесните душевни настани. Во оваа смисла, во анализирањето на различните култури, секоја претстава на фантазијата во сонот, халуцинацијата, изразеното народно творештво, е всушност, мит. Митот и сказната се експресија на архетипови. Директната манифестација на архетиповите во соништата, на пример, е мошне поиндивидуална, помалку разбирлива, и понаивна отколку во митовите (Jung, 1981, 5).

Јунг го позајмува терминот нуминозно од Ото, и обилно го користи, во смисла слична на таа кај Ото. Нуминозното е опасно, привлечно, магично, ${ }^{3}$ табу, извонредно (Jung, 1981, 28). Архетиповите имаат нуминозна содржина и се релативно автономни. Тие не се интегрираат само преку рационален пат, туку треба да им се пристапи дијалектички Jung $(1981,40)$. Меѓу употребата на нуминозно на Јунг и оригиналната концепција на Ото постојат разлики - секако дека читањето на идејата на Ото е определено и ограничено од потребите на Јунг за нејзиното удобно вметнување во неговата теорија. Во психолошките истражувања на нуминозните искуства во Јунговската традиција им се пристапува со особена почит: ако се земе Јунговата концепција за потсвесното, како нешто многу поекстензивно од репримираното потсвесно на Фројд, тогаш секое стапување во контакт на потсвесното и на егото е, речиси per definitionem, трансцендентно искуство, определува МекКена (MacKenna, 2009, 167). Така, тој смета дека иако архетипскиот материјал е во врска со некаков специфичен вид на нуминозно искуство, ова не треба автоматски да се идентификува со чувствувањето на ну-

\footnotetext{
2 Јунг споменува дека терминот архейий се појавува кај Филон Александриски, како референца на imago Dei во човекот. Терминот е употребен неколку пати кај Псевдо Дионисиј Ареопагит. Додека кај Августин го нема терминот, го има концептот. Во De diversis quaestionibus LXXXIII тој пишува за ideae principales, кои самите не се формираат, туку се содржат во божественото позна-

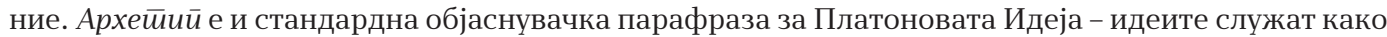
парадигми за стварите. За своите потреби Јунг го определува терминот архейий како корисен, затоа што соодветно укажува на содржината на колективното несвесно при истражувањето на архаичните (или примордијални) типови на нешта, односно, универзалните слики што постоеле уште во најдалечното минато. Архаичната племенска митско-ритуална (а потем фолклорна) традиција се однесува на архетиповите модифицирани на определен начин: тие веќе не се содржини на несвесното, затоа што се трансформирани во свесни формули што се учат низ преданието, најчесто во езотерична форма. Митот и обичната сказна се одличен показател на архетиповите, Jung (1981, 4 - 5). За употребата на терминот повеќе во Тодоровска $(2016,263)$.

3 Под „магично“ не мисли на ист тип на магично(ст) како припадниците на француската социолошка школа, како Диркем, Moc (Mauss) и Убер (Hubert), ниту главниот теоретичар на симпатетичката магија од англиската антрополошка школа (и пошироко), Џ. Џ. Фрејзер (J. G. Frazer).
} 
минозното како кај Ото. МекКена признава дека при ваквата слободна употреба

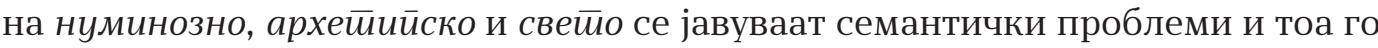
разрешува употребувајќи ги наизменично, но невнимателно (особено имајќи предвид дека статијата е насловена „Од нуминозното до светото“). Очигледно е дека наизменичата употреба создава проблеми во теориите за религијата. Разбирањето на нуминознойо на Ото кај Јунг, МекКена го определува како несоодветно во строга смисла, но продуктивно во широка смисла.

Л. Хаскинсон (Huskinson, 2006, 202) коментира дека Јунг го употребува ну минознойо, најчесто реферирајќи на емоционалното, афективно искуство на несвесното (со особено акцентирање на архетиповите, комплексите и психопатологијата), опишувајќи го како неискажливо, мистериозно, свето, застрашувачко и слично - како признавање на нешто кое оди не само контра гордоста, туку и контра длабоко всадениот страв дека свесноста би ја изгубила предноста или супериорноста (ова соодветствува со изворното акцентирање на ирационалното, на непоимното, од страна на Ото). Нуминозното има ужаснувачки моќи, вознемирувачки емоционални ефекти, и со тоа што неизбежно и содржи и предизвикува амбивалентност, тоа е или лечебно или деструктивно, но никогаш индиферентно. Така, Хаскинсон наведува дека нуминозното е способно за верни трансформации, конверзии, илуминации, емоционален шок, удари на судбината. Сепак, Хаскинсон е во право кога забележува дека употребата на Јунг на терминот на Ото, а со тоа и на подоцнежните коментатори на Јунг, е погрешна. Јунг пребрзо и некритички го инкорпорира терминот во неговата теорија, иако нуминозно не е, строго говорејќи, применливо во многу аспекти на неговата психолошка теорија, со особен акцент на процесот на индивидуизација. Хаскинсон смета дека она на кое треба да се обрне внимание е употребата на свейо кај Ото и употребата на нуминозно кај Јунг. Разликата во значењето на нуминозното искуство и она кое е свето е критична за развојот и лечењето на личноста кои се во центарот на теоријата на Јунг. Според Хаскинсон (иако не е прецизно наведено од каде го извлекува тоа), нуминозното искуство“... не може да предизвика прогресивна промена или богатење на егото, затоа што иако средбата со нуминозното е преобилна, таа нема цел; напротив, само преку искуството на светото личноста се раѓа повторно во Себе (односно како 'Selfhood')“, Huskinson (2006, 210).

Врската меѓу Елијаде и Јунг, т.е. употребата на Елијаде на концепцијата на архетиповите на Јунг е сложена, со тоа што Елијаде го употребува терминот како синоним за йримерен моgел или йараguг̄ма (како Е. д’Opc/E. D’Ors) - са-

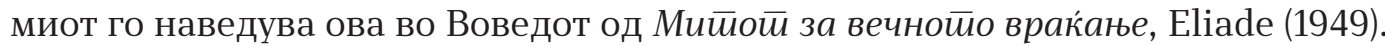


Според некои автори Елијаде директно ја користи идејата на Јунг, според други автори го употребува грубиот скелет, полнејќи со соодветна содржина од неговиот еклектички пристап кон религиите. Така, на пример М. Л. Рикетс (M. L. Rickets) ја покажува употребата на Елијаде на концептуалната рамка на Јунг, Rickets (1973). Според Џ. Мекуари (Масquarrie, 1973, 222, 339)) архейий кај Елијаде не е употребуван како во смислата што ја подразбира Јунг, но, тој се повикува на она кое Елијаде го пишува за архетиповите, а не на компа-

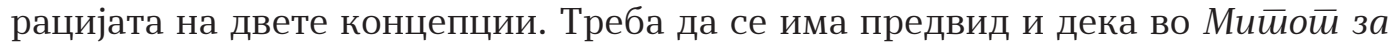
вечнойо враќање Елијаде пишува дека се дистанцира од концепцијата на Јунг и употребува Августиновски концепт, а самиот Јунг исто така го позајмува

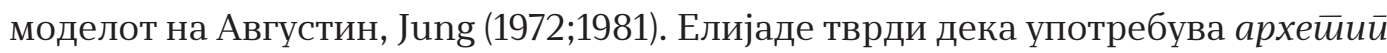
во смисла на моgел или йараguг̄мa, а не во смислата на Јунг. Според некои автори, меѓутоа, токму оваа употреба е решавачка кај Јунг, а интерпретацијата на хиерофаниите како религиозни симболи на Елијаде е токму во рамките на разбирањето на Јунг на архетиповите, Jacobi $(1982,151)$. А. Барбоса да Сиува (А. Barbosa da Silva) тврди дека примери на Јунгови концепти што се наоѓаат низ теоријата за светото на Елијаде се примордијалното, архаичното, Центарот, личното и колективното несвесно, coincidentia oppositorum, сенката, Barbosa da Silva $(1982,151) .^{4}$

H. Спинето (N. Spineto) претпоставува, повикувајќи се на други автори, дека Елијаде го споменува Д’Орс, со кого исто така нема претерана сличност, во обид

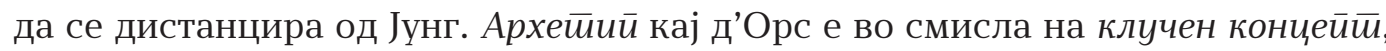
што е прилично широко и не сосема применливо кај Елијаде, Spineto (2008, 368). Спинето смета дека „херменевтиката“ на Јунг и на Елијаде често следи паралелни линии, но идеите на двајцата не се преклопуваат и затоа не може да се тврди дека Елијаде го употребува Јунговиот концепт за архетип. Спинето идентификува три употреби на архейий кај Елијаде: дескриптивно значење (архетипот како израз на архаччна онӣолог̄uја, со „Платоничка структура“); егзистенцијално значење (архетипот како консеквенција на граничните ситуации која се открива во моменти на свесност за сопствената позиција во космосот);

\footnotetext{
4 Да Сиува заклучува дека иако Елијаде позајмува од концептуалната рамка на Јунг, се чини дека е свесен за редукционистичката гледна точка - во смисла на тоа дека Јунг ги опишува и објаснува религиските феномени преку колективното несвесно. Да Сиува во ова го гледа поставувањето на Елијде на ново, четврто подрачје (покрај трите на Јунг), подрачје на транссвесното, кое го смета за тесно поврзано со нуминозното искуство. Потеклото на транссвесното според Елијде е во егзистенцијалните ситуации, смета Да Сиува. Се работи за par excellence егзистенцијалистички потег: граничните егзистенцијални ситуации, она кое Елијаде го нарекува еіззистеиецијални кризи, тој ги лоцира на средина меѓу оние од концепцијата на П. Тилих (P. Tilich) и концептот за граничните ситуации (во кои се добива и свесност за случајноста и нужноста, за минливоста и вечноста) на К. Jасперс (K.Jaspers), Barbosa da Silva (1981, 122).
} 
и морфолошко значење (архетипот е структурален елемент на религискиот феномен). Архетипот како дескриптивен концепт, анализира Спинето, Елијаде го користи за реконструкција и интерпретација на определени историски (односно, свето-историски) ситуации на архаичните општества. Архетипот не е само примерен модел кој архаичното општество го реактуализира преку митови и ритуали, туку поседува примордијален и универзален карактер, затоа што е неразделно поврзан со човековата егзистенција Spineto $(2008,369)$. Ова е, бездруго, точно, затоа што и самиот Елијаде десетици, стотици пати го повторува низ својот огромен опус. Митот е изворната сказна за иницијалното свето во светот, и одржувачка, перформативна и суштинска сказна за одржувањето на свет свет, безбедна средина, космос во кој религиозниот човек чувствува дека припаѓа, и за чие одржување носи одговорност.

\section{Важноста на светото време и приврзаноста кон светите места}

Митовите се свети сказни во кои се раскажува за иницијалната светост на Почетокот на светот, за космогонијата, за првата хиерофанија, за дејствата на светите предци. Како што беше спомнато, со раскажувањето на митот се реактуализира светото време од Почетокот, од „тоа време“, како што Елијаде го нарекува (illud tempus; illo tempore), се враќа (дел од) светоста што се изгубила или истрошила со изминувањето на времето. Homo religiosus ја има самонаметнатата задача да го одржува светото во светот, за светото да (може да) му овозможува убаво уреден, безбеден свет. Опаѓањето на светото во светот е неминовно, но се верува дека во религиозниот култ светите времиња и места ја повикуваат таа изворна, суштинска светост. Елијаде е благодарен на Ото, за тоа што се обидел да ги истражува не поимите за Бог и религијата, туку видовите на религиозни искуства. На Елијаде му се допаѓa ganz andere конструкцијата на Ото, затоа што се работи за реалност која не може да биде именувана, Eliade (1965, 15 - 16). Со оглед на спротивставеноста на светото и профаното, односно разликата во онтолошката вредност, меѓу светите и профаните простори и светите и профаните времиња постои апсолутна нехемогеност, односно хетерогеност (светото го прекинува профаното и обратно). Екстериоризацијата на светото нема ништо профано, траењето на вообичаената профаност од секојдневниот живот го има светото како подлога, или како позадина, како нешто што иницијално го овозможило, но не е директно и очигледно присутно. Концепцијата за хиерофаниите не забележува континуитет: во секоја од нив има мистериозен чин, манифестација на нешто од сосема различен вид, реалност која не припаѓа на вообичаениот свет. Сепак, 
ова се случува низ, преку, и во објектите (и настаните, квалитетите, личностите) кои се интегрален дел од вообичаениот, профан свет. Објектите преку кои се манифестира светото престануваат да бидат обични објекти од вообичаениот свет и стануваат онтолошки повредни од другите. Амбивалентноста се појавува така што преку манифестирањето на светото, објектот станува нешто сосема друго, а сепак останува (барем навидум) ист и продолжува да партиципира во средината која го опкружува.

Една од основните карактеристики на сфаќањето на светот на религиозниот човек е дека просторот не е хомоген. Светиот простор е силен, значаен простор, оние простори кои не се свети се без структура и конзистентност, аморфни. Поради онтолошката и аксиолошка значајност на светиот простор, кај верникот се подразбира силна и специфична врска со него, копнеж по него. Дури и надвор од религиозните чувства, кон важните места од животот (поврзани со настани или траења од минатото) се чувствува речиси посветена почит и трогнатост. Животот подразбира искусување на свет исполнет со значајни места, Relph $(1976,1)$. Поврзувањето со местата е карактеристично чувство од сферата на религиозната посветеност. Идентификувањето со одредени места подразбира потструктура на себеидентитетот на личноста, што се состои од широки поими за физичкиот простор во кој се живее, (Proshansky, Fabian и Kaminoff $(1983,59)$. Поврзувањето, односно идентификувањето со местата е комплексна когнитивна структура што се карактеризира со множество на специфични ставови, вредности, мисли, значења и однесувања, Proshansky et al. (1983, 62).

Елијаде смета дека за религиозниот човек, просторната нехомогеност се изразува во опозицијата меѓу свет простор - единствениот реален и реално постоечки; и сиот друг простор кој го опкружува. Ова религиозно искуство тој го поставува како примордијално искуство што й претходи на сета рефлексија за светот, затоа што токму поделеноста во просторот прави светот да биде создаден, откривајќи ја централната оска (или оската на светот, axis mundi) како референтна точка за секакво натамошно ориентирање. Оваа хиерофанија е и откривање на апсолутна реалност, која е спротивставена на нереалноста на сето друго кое ја опкружува. Елијаде инсистира на тоа дека „...манифестацијата на светото онтолошки го фундира светот“, Eliade $(1965,26)$. Идејата е дека за религиозниот човек светиот простор поседува егзистенцијална вредност - без претходна ориентација, без фиксен центар, ништо не може да почне, ништо не може да биде. Системот на светот подразбира и дека основите на храмовите се спуштаат длабоко до пониските региони, Eliade (1965, 38 - 41); двете основни концепции во ова верување се дека секое создавање е повторување на космогонијат и дека сѐ што е некако фундирано е во центарот, Eliade (1949, 27). 
Колку и да се шири територијата на оската на светот, космосот што го претставува е секогаш совршен. Светите места служат и како слика на светот (imago mundi), со смисла на концентрирана светост, на свет свет во мало. Какви и да се димензиите на просторот кој на човекот му е познат и во кој се чувствува најдобро ситуиран (куќата, селото, градот, земјата), религиозниот човек секогаш има потреба да постои во организиран свет, во космос, Eliade (1965, 44). Еден од дијалектичките проблеми во логиката на верувањето во светото е што светото се поставува како истовремено нешто сосема друго (идејата за светото како ganz andere), и како нешто сосема познато и блиско, безбедната средина на познатиот космос. Идејата е дека оската на светот е нешто сосема друго, кое креира нешто сосема познато и блиско (космосот). Вертикалите кои служат како свети планини, карпи или дрвја, а кои човекот ги гради, се истовремено познати и блиски (тој ги има изградено) и нешто сосема различно од него. Низ корпусот на Елијаде има цел комплекс на митови, симболи и ритуали ја претставува тешкотијата неповредено да се пенетрира во еден центар, а од друга страна, и истовремено, множество митови, симболи и ритуали што го покажува тој центар како достапен и близок.

\section{Непријатно непознатото како профан еквивалент на нуминозното}

Поради неговата извонредна одделеност од профаното, тешко е за светото да се говори со јазикот од профаната сфера. Така, тоа мора да се дефинира низ концепти и со термини од профаното искуство, постојано нагласувајќи дека тоа се недоволни и несоодветни мисловни и јазички конструкции. Вообичаено се смета дека чувството на возвишеното, предмет на истражување на естетиката, и чувството на непријатно непознатото (unheimlich), ${ }^{5}$ предмет на разгледување на психологијата, се (нешто како) профани еквиваленти на чувството на нуминозното. Не се токму еквивалентни, секако, затоа што се работи за различни нивоа на постоењето, но служат за да помогнат да се доведе до умот дел од чувствувањето на нуминозното. Искуството на непријатно непознатото може само аналогно да се разгледува како слично на нуминозното, и со тоа да помогне да се определи, барем индиректно, нуминозното чувство. Е. Јенч (Е.

\footnotetext{
5 Терминот unheimlich тешко може да се преведе со само еден збор: во англискиот јазик е решено како uncanny, во италијанскиот доминира il perturbante, иако Ф. Орландо (F. Orlando) го употребува il sinistro, Orlando (1982), а фигурира и како lo spaesamento (на пример кај Berto, 1999). Во францускиот јазик најчесто се употребува l'inquiétante étrangeté (вознемирувачка $\bar{u} y z ́ о с \bar{u})$ предложено од M. Бонапарт (M. Bonaparte) во 1919 година, што е доста добро решение, иако не директно од (un) heim (во смисла на недомашно, нетатковинско). Како македонски превод за соодветно може да се смета вознемирувачко нейознайо, или, како што е одбрано во овој слүчај, нейријайно нейозна$\bar{u} о$. Доколку акцентот се стави на навестувањето на непријатност до степен на злокобност, како според О. Чемерски, може да се преведе со зловесно - навестува зло, односно „виси“ зло(кобност).
} 
Jentsch) смета дека кованицата во германскиот јазик е мошне добро избрана. Unheimlich изразува дека чувството се јавува кога некој се наоѓ „недома“ (nicht zu Hause) во одредена ситуација, кога не се чувствува „во елемент“, кога ситуацијата му е непозната, или барем му се чини дека му е непозната. Акцентот во ова објаснување е во недостигот на ситуациона ориентација. Она кое ни е познато, не само што е добредојдено, туку е и очигледно, себеразбирливо. Како извор на чувството на непријатно непознатото Јенч ја определува интелектуалната несигурност. Поради непријатноста што ја будат, необичните луѓе и непретходените ситуации ја предизвикуваат таа карактеристична претпазливост. Тоа се должи на процесот во врска со нив, кој ја надминува можноста за објаснување, или чии услови на потеклото се непознати, Jentsch $(1995,8)$. Тука може да се вбројат извонредната техника на виртуоз или на хирург, наспроти изведувач кој голта цигли или крши камења од својата глава, или пак факир кој се самозапалува, дури и во ситуации на вистински восхит. Ова чувство се објаснува преку зачуденоста околу тоа како се имаат создадено условите за необичното достигнување, односно за потеклото на необичната способност или вештина Jentsch $(1995,9)$. Како една од главните причини за појавувањето на чувството на непријатно непознатото, Јенч ја определува несигурноста дали некое наизглед живо суштество навистина има душа или не, и обратно, дали некое наизглед неживо суштество нема, всушност, душа. Ова чувство доаѓа од сомнежот што се јавува опскурно во свеста. Јенч се повикува на расказот Песочниой човек на Е. T. А. Хофман (Е. T. A. Hoffmann). ${ }^{6}$

Во есејот „Непријатно непознатото“, Фројд го определува непријатно непознатото како класа на застрашувачки нешта кои нѐ водат назад кон она кое познато и блиско, Freud (1919). Тој не се согласува со ставовите на Јенч дека се работи за страв од непознатото и дека чувството е базирано на интелектуална несигурност. Фројд прво дијалектички ја разгледува етимологијата на термините heimlich и unheimlich: првата дефиниција на heimlich е дека припаѓа на домот, е пријателско, блиско, познато, припитомено, интимно, удобно, одомаќено, безбедно; а според втората дефиниција на heimlich, тоа е нешто скриено, тајно, затскриено од видот, измамничко, нешто мистично, окултно, алегориско, божествено. Во сфаќањето на Фројд heimlich е нешто кое е скриено и од самото себе. Unheimlich, пак, како спротивно на него, според првата дефиниција е нешто

\footnotetext{
6 Идејата која ја воведува Хофман, а која Јенч на овој начин ја инаугурира во истражувањето, е едно од најпровокативните прашања во современата роботика, во теоријата за Непознатата долина (Uncanny valley), хипотеза во полето на роботиката според која репликите на човечки тела и функции кои се слични, но не совршено исти со оние на вистинските човечки суштества предизвикуваат чувство на непријатност и одбивност, абјектно чувство, или дури и страв и ужаснатост, за прв пат разработена кај Mori (1970).
} 
недомашно, непознато, неприпитомено, неудобно, чудно, морничаво, а според втората (помалку вообичаена) варијанта, тоа е нескриено, нетајно, достапно на познание, нешто што треба да биде тајно, но се открива. Непријатно непознатото се јавува при чувствувањето вознемиреност поради непознатиот аспект на околностите, ситуација што не може да биде едноставно надмината, затоа што овој аспект не може да биде објаснет со вообичаени рационални термини. Скриеноста, појавноста, познатоста и несигурноста предизвикуваат збунетост поради нивната амбивалентност. Држејќи се конзистентно до оваа поента, Фројд не се согласува со инсистирањето на интелектуалната несигурност, а со тоа и со акцентирањето на Јенч на морничавоста на автоматот во Песочниой човек - за Фројд, еден од главните извори на чувството на непријатно непознатото е токму Песочниот човек, Тодоровска (2015, 180 -187; 2016, 208 - 210).

Очигледно е дека концептот за искуството на нешто сосема друго никако не е идентичен со концептот за непријатно непознатото, затоа што додека ganz andere е дел од извонредноста и мистеријата на светото, unheimlich функционира повеќе на вообичаеното подрачје од психичкиот живот. Во определувањето на Ото дека сосема другото е над сферата на вообичаеното, интелигибилното и познатото, дека паѓа надвор од границите на она кое e heimlich, исполнувајќи го духот со празно чудење и восхит, се забележува идејата за средба со другото, но без негово асимилирање, без можноста да се спореди другото со она познатото и блиското. Сосема другото е толку непознато и неблиско, што не може да биде третирано со познати востановени параметри. Постои силна спротивставеност меѓу двете - од една страна другото не може да биде редуцирано на категориите на субјектот и преку нив разбрано, од друга страна, субјектот сепак не се брише себе си за да му се предаде на она кое лежи надвор од него, поради содржинската и онтолошка дискрепанција меѓу нив. Нуминозното е нешто сосема друго, потполно различно. Кога верникот и теоретичарот се обидуваат да го споредат со нему слични поими и со чувства кои се приближни, но никако идентични со чувствата на фасцинирана ужаснатост, на треперечки страв и трогната привлеченост и желба за асимилација, кои средбата со нуминозното ги предизвикува кај верникот, нуминозното спречува какво било конзистентно поимно познание, спречува формулирање соодветни дескрипции, спречува каква било поврзаност со него, освен преку чувствата на стравопочитувачка предаденост и желба за спојување со него, што не се токму искажливи. Истражувањето на нуминозното е можно само со антиципирано потфрлање во обидите тоа да се лимитира во областа на рационалното познание, да се поими, да се искаже, да се објасни низ елементите од ненуминозната, односно профаната стварност. 


\section{Заклучок}

Оваа статија беше обид да се позиционира темата на симпозиумот, „Психологија за сите“, во една од суштинските проблематики од теориите за религијата - искуството на светото и важноста на верувањето во светото за религиозниот човек. Емоциите што светата реалност ги предизвикува не може точно и соодветно да се искажат со терминологијата од профаната стварност. Чувството на светото е комбинација на стравопочитувачко треперење, фасцинација, восхитеност, трогнатост, желба за асимилација, што не се јавува при секојдневните ситуации од обичното, несвето живеење. Емоционалноста на homo religiosus во искуството на светата реалност се разликува од искуствата што не се поврзани со светото не по степен, туку по вид. За верникот, емоциите кон светите простор и време како суштински онтолошки категории се суштински важни за функционирањето на религиозниот култ. Разгледувањето на дел од комплексната емоционалност на homo religiosus подразбира истражување на религиозните и емоционалните аспекти на искусувањето на светото, низ концептите за нуминозното на Ото, низ концептите за парадигматичноста и перформативноста на митот како основа на религијата на Елијаде и преку употребата на архетиповите кај Јунг (и Елијаде). Покрај ова, искусувањето на светото, со тоа што не може да биде директно и суштински сфатено, искажано и пренесено, може, со резерва, да се разгледува низ неговите профани (квази) еквиваленти, како на пример, чувството на непријатно непознатото. 


\section{Литература}

Almond, P. C. (1984). Rudolf Otto: An Introduction to His Philosophical Theology. Chapel Hill: University of North Carolina Press.

Barbosa da Silva, A. (1982). The Phenomenology of Religion as a Philosophical Problem (Doctoral Thesis at the University of Uppsala). Uppsala: CWK Gleerup.

Berto, G. (1999). Freud, Heidegger. Lo spaesamento. Milano: Bompiani.

Durkheim, É. (1968). Les formes élémentaires de la vie religieuse. Paris: PUF.

Eliade, M. (1949). Le Mythe de l'éternel retour: archetypes et repetition. Paris: Gallimard.

Eliade, M. (1965). Le sacré et le profane. Paris: Gallimard.

Freud, S. (1919). Das Unheimliche. Zeitschrift fur Anwendung der Psychoanalyse auf die Geisteswissenschaften V, 97-324.

Huskinson, L. (2006). Holy, Holy, Holy: the misappropriation of the numinous in Jung. In A. Casement \& D. Tacey (Eds.) The Idea of the Numinous, Contemporary Jungian and Psychoanalytic Perspectives (pp. 200-211). Hove and New York: Routledge.

Jentsch, E. (1995). On the Psychology of the Uncanny. Roy Sellar (trans.) Angelaki 2.1, 7-16.

Jolande J. (1972). C. G. Jung: Psychological Reflections - a New Anthology of his Writings, Bollingen Series, 31. New Jersey-New York: Princeton University Press.

Jung, C. G. (1972). Four Archetypes. London: Routledge\&Kegan Paul.

Jung, C. G. (1981). The Collected Works of C. G. Jung, Vol. 9 (Archetypes of the Collective Unconscious), R. F. C. Hull (trans.). London: Routledge.

MacKenna, C. (2009). From the numinous to the sacred. Journal of Analytical Psychology, 2009, 54(2), 167-182.

Macquarrie, J. (1973). 20th Century Philosophical Thought. London: SCM Press.

Masahiro, M. (1970). The Uncanny Valley. K. F. MacDorman, N. Kageki (trans.) IEEE Robotics\&Automation Magazine, 19 (2), 98-100.

Orlando, F. (1982). La retorica freudiana. Torino: Einaudi.

Proshansky, H. M., Fabian, A. K., \& Kaminoff, R. (1983). Place identity: physical world socialization of the self. Journal of Environmental Psychology, 3, $57-83$.

Relph, E. (1976). Place and placelessness. London: Pion Limited. 
Rickets, M. L. (1973). In Defence of Eliade - Toward Bridging the Communication Gap Between Anthopology and History of Religions. Religion (Journal of Religion and Religions), 3, 1973, 13-34.

Rudolf O. (1920). Das Heilige - Über das Irrationale in der Idee des Göttlichen und sein Verhältnis zum Rationalen. Breslau : Trewendt-Granier.

Spineto, N. (2008). The notion of archetype in Eliade's writings. Religion, 38, 366-374.

Тодоровска, М. (2015). Нуминозното, возвишеното и непријатно непознатото во теоријата за светото на Рудолф Ото. Филозофска йрибина, 38 (18), 173 - 194.

Тодоровска, М. (2016). Дијаболичнайа ӣpироgа на свейойо. Скопје: Филозофски факултет. 


\title{
EXPERIENCING THE SACRED: EMOTIONAL ASPECTS OF RELIGIOUS BELIEF
}

\section{Marija Todorovska}

\begin{abstract}
The paper attempts to briefly explore the relation between the understanding of the experience of the sacred in the study of the basis of religion and the complex emotionality of religious life, as well as to shed some light on the emotions that the experience of the sacred (or numinous) reality provokes, through three main points of focus: the experience of the sacred by the religious man (homo religiosus) in the theories of R. Otto and M. Eliade; the connection between the Jungian concept of archetypes and the paradigmatic importance of myths as sacred tales; and the feeling of the uncanny as a profane (quasi) equivalent of the feeling of the numinous. Along these lines, the concept of sacred space, as a crucial ontological category in the research of the sacred, is briefly explained as formative in the functioning of the religious cult and the religious belief, both in the archaic communities and persistently in a contemporary context.
\end{abstract}

Keywords: sacred, numinous, Otto, Eliade, Jung, uncanny, archetype 